\title{
Course Outcomes, Specific Performance Indicators, Rubrics and Continuous Quality Improvement in a Core Undergraduate Electrical Engineering Course
}

\author{
Hassan Tariq Chattha, Khawaja Bilal Mahmood, Abdul Rahman Alkassem, Saleh Al-Ahamdi \\ Department of Electrical Engineering, Faculty of Engineering, Islamic University of \\ Madinah, Kingdom of Saudi Arabia
}

\begin{abstract}
This paper presents the course outcomes, specific performance indicators, rubrics and teaching / learning methodologies / strategies adopted related to the 'Signals and Systems' course taught to the bachelor's students of Electrical Engineering. It will discuss the mapping of course outcomes, and specific performance indicators with the ABET Student Outcomes, the rubrics used for the assessments and evaluations related to each specific performance indicator and how Continuous Quality Improvement (CQI) is implemented in the course of 'Signal and Systems' by modifying the course teaching / learning strategy in course delivery related to the failing course outcomes. And the impact of these teaching strategies on the performance of students is discussed in detail. And conclusions are drawn based on the teaching and learning methodologies adopted for improvement.
\end{abstract}

\section{Introduction}

Over a very long period, the main teaching and learning strategy has been the traditional ContentBased Education (CBE) which is a teacher-centred approach and mainly focuses on contents using textbooks and considers syllabus as rigid \& nonnegotiable. This approach sees students as passive learners, just listening and trying to absorb the given information. This approach provides such an environment to the students having very less focus on whether the students have ever learned the given material. The approach makes students exam oriented and CGPA driven. It emphasizes on what the teacher hopes to achieve. And the graduates produced through this strategy are not well-prepared for the requirements of the job market. It emphasizes very less focus on soft skills such as communication, interpersonal-, and analytical skills, etc. needed for different jobs.

Outcome-Based Education (OBE) is a paradigm shift in education. It is not what the teacher has taught; it's what the student has learned. It focuses on the desired end results and curriculum instruction and assessments are taken according to the exit outcomes It is a student-centered approach creating more calmness and composure between the teacher and the students [1-2]. Even though the teacher still has the final authority, but he/she is acting more as a facilitator, guiding the students and facilitating them in their learning process. It has more directed and coherent curriculum. OBE includes the modifications and amendments in curriculum, assessments and teaching strategies for reflecting the achievements of high order learnings and mastering it rather than just accumulating the course credits. This approach sees students as active learners. It enables the students to complete a task with flexible time frames. The assessment is a continuous process which involves the curriculum, instruction and assessment be taken according to the exit outcomes. Through OBE, the graduates will be more well-rounded graduates which make them more relevant to industry and other stakeholders. And one of the very significant benefits of OBE is that it has a Continuous Quality Improvement (CQI) in place which ensures the constant review of teaching and learning strategies based on outcomes. It connects the Vision and Mission of the institution, Program Educational Objectives (PEO), Students Outcomes (SO), and Course Outcomes (CO) as shown in the Figure 1.

Vision and Mission of the

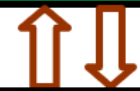

Proaram Educational

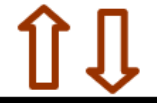

Student Outcomes (SO)

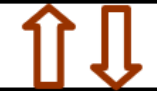

Course Outcomes (CO)

Figure 1. A Model Hierarchy of Outcomes

PEOs are comprehensive declarations that outline the expectations of the graduates to achieve within some certain years after the completion of the program. Program educational objectives depends on the requirements of the program's aspects and components [3-4]. Student Outcomes (SO) mentions the expectations for the students to learn and are able to perform heretofore the completion of that specific 
program. It describes what students should know (cognitive), think (attitudinal) or do (behavioural) when they have completed a program. Each program needs to have documented SOs for making the graduates of achieving program educational objectives. We have applied ABET Student Outcomes which are 11 outcomes in total (SO-1 to SO-11) [5-6].

The Course Outcomes (CO) are soft or technical skills which every student needs to attain before completing that specific course [7]. The COs should be made in such a way that they are measurable and can be linked to the SOs and PEOs [8]. The Performance Indicators (PI) are specific, measurable statements identifying the performance(s) required to meet the outcomes, confirmable through evidence. Performance Indicator describes student outcomes in "measurable" terms provide a basis for teaching/learning strategies and data collection. Performance Indicators (PI) are concrete, measurable statements indicating the specific characteristics students need to show for the demonstration of required achievement of the student outcome. The characteristics of PIs include the use of action verbs which highlight the depth to which students need to demonstrate the performance. It is content referent and is free of terms that express the value (e.g. effectively, accurately, completely, etc.). Those express values with a scale and descriptions in the form of a rubric. Assessment is one or more processes that indicate, gather, and prepare data for evaluating the achievement of student outcomes. Evaluation is the process of determining the degree of achievement of desired student outcomes.

For ensuring that the SO and PEO are suitable, employable and in accordance with the job requirements of the modern era, continuous assessment and evaluation of these sets of outcomes needs to be done periodically. Therefore, continuous quality improvement (CQI) is a significant constituent in OBE [7]. The inputs such as the program delivery and assessment methods are modified as per requirement for ensuring that student performances match the desired SO. This needs a systematic approach of measuring SOs attainment from student assessments [9-11].

This paper represents the course learning outcomes, and specific performance indicators related to the course 'Signals and Systems' in the degree plan of Bachelor of Science in Electrical Engineering. And for the implementation of Continuous Quality Improvement (CQI) the modifications performed in teaching and learning strategies/methodologies in the course delivery related to the failing course learning outcomes and discussing the effects of these teaching strategies on the performance of students.

\section{Signals and Systems Course 2.1. Course Outcomes (CO)}

The measurable course outcomes developed for and used in the course 'Signals and Systems' are the following with the action verbs used are highlighted in bold:

1. Perform the transformation of the independent variable (amplitude and time domain) operations on Continuous-Time (CT) and DiscreteTime (DT) signals.

2. Draw the continuous-time and discrete-time complex exponential and sinusoidal signals.

3. Classify systems in terms of continuoustime or discrete-time, linear or non-linear, timeinvariant or time-varying, and causal or noncausal.

4. Determine LTI system response by applying the convolution sum and convolution integral techniques.

5. Evaluate the properties of Linear Time Invariant (LTI) systems using their impulse response.

6. Characterize LTI systems by representing their differential and difference equations using block diagrams.

7. Apply the Fourier series for analyzing the frequency spectrum of periodic signals.

8. Apply continuous-time and discrete-time Fourier transform for analyzing the frequency spectrum of periodic and aperiodic signals.

9. Conduct research to study and examine the real-life applications of convolution techniques, Fourier series and Fourier transform.

10. Apply Z-transform, inverse Z-Transform and its properties for the analysis of LTI systems.

\subsection{Specific Performance Indicators}

A big database of measureable specific Performance Indicators (PI) is developed for use in an undergraduate program of Electrical Engineering [12]. The specific PIs are classified in terms of Bloom's 3 learning domains (Cognitive, Affective, Psychomotor) with the respective learning levels. The specific PIs developed and used for the course 'Signals and Systems' for identifying the student performances for obtaining the corresponding $\mathrm{CO}$ and SOs are as follows.

[CO-1_SO-1_PI-59] Cognitive: Applying Perform various amplitude domain operations such as amplitude Scaling, multiplication, addition, subtraction and time domain operations such as Time shifting, Time reversal and Time scaling etc. on continuous-time and discrete-time signals.

[CO-2_SO-1_PI-80] Psychomotor: Complex overt response Represent diagrammatically the complex exponential and sinusoidal continuous- and discrete- 
time signals; Properly label the diagram; find the fundamental period.

[CO-3_SO-1_PI-58] Cognitive: Understanding Explain or justify the classifications of system and/or signals as being continuous-time or discrete-time, linear or non-linear, time varying or time-invariant, periodic or aperiodic, stable or unstable, and causal or non-causal.

[CO-4_SO-11_PI-40] Cognitive: Analyzing Determine LTI system response by performing convolution sum and convolution integral techniques based upon the type of input signal.

[CO-5_SO-11_PI-38] Cognitive: Evaluating Analyze LTI systems based on their impulse response; find the various characteristics of LTI systems such as causal/non-causal, memory less/with memory, stability etc.

[CO-6_SO-11_PI-37] Cognitive: Analyzing Use given differential (continuous time) and difference equations (discrete time) to obtain the block diagram representation of a LTI system; solve these equations using given parameters to find the explicit relationship between input and output.

[CO-7_SO-11_PI-53] Cognitive: Analyzing Analyze the frequency spectrum of periodic CT/DT signals by applying Fourier series and obtain the coefficients of constituent signals; or use given coefficients of harmonically related constituent basic signals to reconstruct the periodic signal.

[CO-8_SO-11_PI-54] Cognitive: Analyzing Analyze the frequency spectrum of periodic and aperiodic CT/DT signals by applying Fourier transform; convert given signal in frequency domain to time domain using inverse Fourier transform.

[CO-9_SO-9_PI-12] Affective: Internalizing values Perform literature survey on given engineering problem/application; Locate requested technical information using the internet, company provided or external resources; provide professional research citations for technical information relevant to the topic of research; assimilate technical information in an organized format for presenting the practicality of application of engineering solutions to existing problems.

[CO-10_SO-11_PI-61] Cognitive: Analyzing Analyze LTI systems by applying Z-transform, inverse Z-transform and its properties; obtain Ztransform of the given signal; draw the region of convergence; find its poles and zeros; or use inverse Z-transform to obtain the time domain signal.
Where $\mathrm{CO}-\mathrm{X}$ is the corresponding course outcome of the course, SO-X is the corresponding ABET Student Outcome mapped to the CO and PI$\mathrm{XX}$ is specific performance indicator with the related number from the data base.

A pie chart showing the corresponding percentages of the revised Bloom's three learning domains covered in this course is shown in Figure 2.

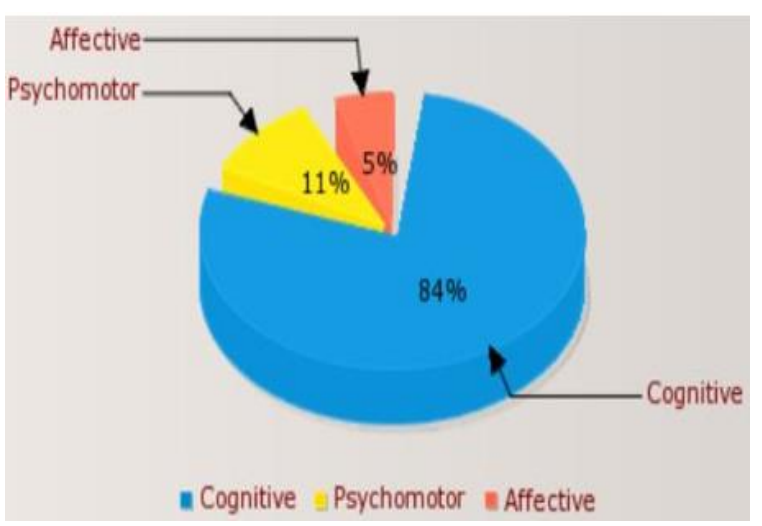

Figure 2. Percentage distribution of assessment activities in Bloom's three learning domains

It is evident that it mainly covers Cognitive domain (84\%) with a small fraction of Affective and Psychomotor domains. The learning levels in each learning domain are categorised into three skills levels i.e. Elementary, Intermediate and Mastery [13] (see Table 1). The percentage skill levels covered by this course are shown in Figure 3. It is clear that it is covering mainly the 'Intermediate skills' i.e. $68 \%$, followed by 'Advanced Skills' of $21 \%$ and 'Elementary Skills' of $11 \%$.

Table 1. Three-levels skills categorization of revised Bloom's three learning domains [13]

\begin{tabular}{|c|c|c|c|}
\hline Skills Level & $\begin{array}{l}\text { Cognitive } \\
\text { Domain }\end{array}$ & $\begin{array}{l}\text { Affective } \\
\text { Domain }\end{array}$ & $\begin{array}{l}\text { Psychomotor } \\
\text { Domain }\end{array}$ \\
\hline Elementary & $\begin{array}{l}\text { 1. Knowledge } \\
\text { 2. } \\
\text { Comprehension }\end{array}$ & $\begin{array}{l}\text { 1. Receiving } \\
\text { phenomena } \\
\text { 2. Responding } \\
\text { to phenomena }\end{array}$ & $\begin{array}{l}\text { 1. Perception } \\
\text { 2. Set } \\
\text { 3. Guided } \\
\text { response }\end{array}$ \\
\hline Intermediate & $\begin{array}{l}\text { 3. Application } \\
\text { 4. Analysis }\end{array}$ & 3. Valuing & $\begin{array}{l}\text { 4. Mechanism } \\
\text { 5. Complex } \\
\text { overt response }\end{array}$ \\
\hline Advanced & $\begin{array}{l}\text { 5. Evaluation } \\
\text { 6. Creation }\end{array}$ & $\begin{array}{l}\text { 4. Organizing } \\
\text { values into } \\
\text { problems } \\
\text { 5. Internalizing }\end{array}$ & $\begin{array}{l}\text { 6. Adaptation } \\
\text { 7. Origination }\end{array}$ \\
\hline
\end{tabular}




\subsection{Rubrics}

\subsubsection{Rubrics for [CO-1_SO-1_PI-59]}

\begin{tabular}{|c|c|c|c|c|c|}
\hline \multicolumn{3}{|c|}{ Course Outcome } & \multicolumn{3}{|c|}{$\begin{array}{l}\text { CO-1: Perform the transformation of the independent variable } \\
\text { (amplitude and time domain) operations on Continuous-Time (CT) and } \\
\text { Discrete-Time (DT) signals. }\end{array}$} \\
\hline \multicolumn{3}{|c|}{ ABET Student Outcome } & \multicolumn{3}{|c|}{$\begin{array}{l}\text { SO-1: an ability to apply knowledge of mathematics, science, and } \\
\text { engineering }\end{array}$} \\
\hline \multicolumn{3}{|c|}{ Performance Indicator } & \multicolumn{3}{|c|}{$\begin{array}{l}\text { P1-59: Perform various amplitude domain operations such as } \\
\text { amplitude Scaling, multiplication, addition, subtraction and time } \\
\text { domain operations such as Time shifting, Time reversal and Time } \\
\text { scaling etc. on continuous-time and discrete-time signals. }\end{array}$} \\
\hline \multicolumn{3}{|c|}{$\begin{array}{l}\text { Highest Expectation } \quad \text { Student } \\
\text { Activity (Sequential with All } \\
\text { Gradable Major Steps) }\end{array}$} & \multicolumn{3}{|c|}{$\begin{array}{l}\text { 1. Write all the mathematical steps correctly of performing the } \\
\text { required amplitude/time domain operations on the given } \\
\text { continuous time and/or discrete time signals } \\
\text { 2. The output signal is drawn correctly and properly labelled with } \\
\text { respect to amplitude and time-axis. }\end{array}$} \\
\hline Score & $\begin{array}{l}\text { Excellent (90- } \\
100 \%)\end{array}$ & \multicolumn{2}{|c|}{ Adequate $(75-89 \%)$} & Minimal (60-75\%) & Unsatisfactory $(0-60 \%)$ \\
\hline $50 \%$ & $\begin{array}{l}\text { Accurately write all } \\
\text { mathematical steps } \\
\text { for performing } \\
\text { required } \\
\text { amplitude/time } \\
\text { domain operations } \\
\text { on the given } \\
\text { continuous time } \\
\text { and/or discrete time } \\
\text { signals }\end{array}$ & \multicolumn{2}{|c|}{$\begin{array}{l}\text { Accurately write all } \\
\text { mathematical steps } \\
\text { for performing } \\
\text { required } \\
\text { amplitude/time } \\
\text { domain operations on } \\
\text { the given continuous } \\
\text { time and/or discrete } \\
\text { time signals }\end{array}$} & $\begin{array}{l}\text { Minor errors to } \\
\text { accurately write all } \\
\text { mathematical steps for } \\
\text { performing required } \\
\text { amplitude/time domain } \\
\text { operations on the given } \\
\text { continuous time and/or } \\
\text { discrete time signals }\end{array}$ & $\begin{array}{l}\text { Major errors to } \\
\text { accurately write all } \\
\text { mathematical steps for } \\
\text { performing required } \\
\text { amplitude/time domain } \\
\text { operations on the given } \\
\text { continuous time and/or } \\
\text { discrete time signals }\end{array}$ \\
\hline $50 \%$ & $\begin{array}{l}\text { Accurately draw } \\
\text { properly labelled } \\
\text { output signal with } \\
\text { respect to amplitude } \\
\text { and time-axis. }\end{array}$ & \multicolumn{2}{|c|}{$\begin{array}{l}\text { Minor errors to } \\
\text { accurately draw } \\
\text { properly labelled } \\
\text { output signal with } \\
\text { respect to amplitude } \\
\text { and time-axis. }\end{array}$} & $\begin{array}{l}\text { Minor errors to } \\
\text { accurately draw properly } \\
\text { labelled output signal } \\
\text { with respect to amplitude } \\
\text { and time-axis. }\end{array}$ & $\begin{array}{l}\text { Major errors to } \\
\text { accurately draw } \\
\text { properly labelled } \\
\text { output signal with } \\
\text { respect to amplitude } \\
\text { and time-axis. }\end{array}$ \\
\hline
\end{tabular}

\subsubsection{Rubrics for [CO-2_SO-1_PI-80]}

\begin{tabular}{|c|c|c|}
\hline \multicolumn{2}{|c|}{ Course Outcome } & $\begin{array}{l}\text { CO-2: Draw the continuous-time and discrete-time complex } \\
\text { exponential and sinusoidal signals. }\end{array}$ \\
\hline \multicolumn{2}{|c|}{ ABET Student Outcome } & $\begin{array}{l}\text { SO-1: an ability to apply knowledge of mathematics, science, and } \\
\text { engineering }\end{array}$ \\
\hline \multicolumn{2}{|c|}{ Performance Indicator } & $\begin{array}{l}\text { P1-80: Represent diagrammatically the complex exponential and } \\
\text { sinusoidal continuous- and discrete-time signals; Properly label the } \\
\text { diagram; find the fundamental period. }\end{array}$ \\
\hline \multicolumn{2}{|c|}{\begin{tabular}{llr|} 
Highest & Expectation & Student \\
Activity & (Sequential with All \\
Gradable Major Steps) &
\end{tabular}} & $\begin{array}{l}\text { 1. Write all the mathematical steps correctly of finding the } \\
\text { amplitude and time-axis values for the given complex } \\
\text { exponential or sinusoidal form of continuous-time and/or } \\
\text { discrete-time signals. } \\
\text { 2. The output signal is drawn correctly and properly labelled with } \\
\text { respect to amplitude and time-axis. }\end{array}$ \\
\hline Score & $\begin{array}{l}\text { Excellent } \\
100 \%)\end{array}$ & $\begin{array}{l}\text { Unsatisfactory } \\
60 \%)\end{array}$ \\
\hline
\end{tabular}




\begin{tabular}{|c|c|c|c|c|}
\hline $40^{\circ}$ & $\begin{array}{l}\text { the mathematical } \\
\text { steps of finding the } \\
\text { amplitude and time- } \\
\text { axis values for the } \\
\text { given complex } \\
\text { exponential or } \\
\text { sinusoidal form of } \\
\text { continuous-time } \\
\text { and/or discrete-time } \\
\text { signals. }\end{array}$ & $\begin{array}{l}\text { Accurately write all } \\
\text { the mathematical } \\
\text { steps of finding the } \\
\text { amplitude and time- } \\
\text { axis values for the } \\
\text { given complex } \\
\text { exponential or } \\
\text { sinusoidal form of } \\
\text { continuous-time } \\
\text { and/or discrete-time } \\
\text { signals. }\end{array}$ & $\begin{array}{l}\text { Minor errors to } \\
\text { accurately write all the } \\
\text { mathematical steps of } \\
\text { finding the amplitude } \\
\text { and time-axis values for } \\
\text { the given complex } \\
\text { exponential or sinusoidal } \\
\text { form of continuous-time } \\
\text { and/or discrete-time } \\
\text { signals. }\end{array}$ & $\begin{array}{l}\text { Major errors to } \\
\text { accurately write all } \\
\text { the mathematical steps } \\
\text { of finding the } \\
\text { amplitude and time- } \\
\text { axis values for the } \\
\text { given complex } \\
\text { exponential or } \\
\text { sinusoidal form of } \\
\text { continuous-time } \\
\text { and/or discrete-time } \\
\text { signals. }\end{array}$ \\
\hline $60 \%$ & $\begin{array}{l}\text { Accurately draw } \\
\text { properly labelled } \\
\text { output signal with } \\
\text { respect to amplitude } \\
\text { and time-axis. }\end{array}$ & $\begin{array}{l}\text { Minor errors to } \\
\text { accurately draw } \\
\text { properly labelled } \\
\text { output signal with } \\
\text { respect to amplitude } \\
\text { and time-axis. }\end{array}$ & $\begin{array}{l}\text { Minor errors to } \\
\text { accurately draw properly } \\
\text { labelled output signal } \\
\text { with respect to amplitude } \\
\text { and time-axis. }\end{array}$ & $\begin{array}{l}\text { Major errors to } \\
\text { accurately draw } \\
\text { properly labelled } \\
\text { output signal with } \\
\text { respect to amplitude } \\
\text { and time-axis. }\end{array}$ \\
\hline
\end{tabular}

\subsubsection{Rubrics for [CO-3_SO-1_PI-58]}

\begin{tabular}{|l|l|}
\hline Course Outcome & $\begin{array}{l}\text { CO-3: Classify systems in terms of continuous-time or discrete-time, } \\
\text { linear or non-linear, time-invariant or time-varying, and causal or } \\
\text { noncausal. }\end{array}$ \\
\hline ABET Student Outcome & $\begin{array}{l}\text { SO-1: an ability to apply knowledge of mathematics, science, and } \\
\text { engineering }\end{array}$ \\
\hline Performance Indicator & $\begin{array}{l}\text { P1-58: Explain or justify the classifications of system and/or signals } \\
\text { as being continuous-time or discrete-time, linear or non-linear, time } \\
\text { varying or time-invariant, periodic or aperiodic, stable or unstable, } \\
\text { and causal or non-causal. }\end{array}$ \\
\hline $\begin{array}{l}\text { Highest Expectation Student } \\
\text { Gradable Major Steps) }\end{array}$ & $\begin{array}{l}\text { 1. Identify the characteristics of the given system/signal } \\
\text { Based on the characteristics, classify the system/signal as } \\
\text { continuous- or discrete-time, linear or nonlinear, time-invariant } \\
\text { or time-varying, digital or analog, periodic or aperiodic, } \\
\text { deterministic or probabilistic, causal or non-causal and energy or } \\
\text { power using logical reasoning and mathematical expressions. }\end{array}$ \\
\hline
\end{tabular}

\begin{tabular}{|c|c|c|c|c|}
\hline Score & Excellent (90-100\%) & Adequate $(75-89 \%)$ & Minimal (60-75\%) & $\begin{array}{l}\text { Unsatisfactory } \\
60 \%)\end{array}$ \\
\hline $40 \%$ & $\begin{array}{l}\text { Identify all the } \\
\text { required } \\
\text { characteristics } \\
\text { accurately of the } \\
\text { given system/signal. }\end{array}$ & $\begin{array}{l}\text { Identify most of the } \\
\text { required } \\
\text { characteristics } \\
\text { accurately of the } \\
\text { given system/signal. }\end{array}$ & $\begin{array}{l}\text { Identify some of the } \\
\text { required characteristics } \\
\text { accurately of the given } \\
\text { system/signal. }\end{array}$ & $\begin{array}{l}\text { Unable to identify } \\
\text { most of the required } \\
\text { characteristics } \\
\text { accurately of the } \\
\text { given system/signal. }\end{array}$ \\
\hline $60 \%$ & $\begin{array}{l}\text { Based on } \\
\text { characteristics, } \\
\text { classify } \\
\text { system/signal } \\
\text { continuous- } \\
\text { discrete-time, linear } \\
\text { or nonlinear, time- } \\
\text { invariant or time- } \\
\text { varying, digital or } \\
\text { analog, periodic or } \\
\text { aperiodic, } \\
\text { deterministic or } \\
\text { probabilistic, causal } \\
\text { or non-causal and }\end{array}$ & $\begin{array}{l}\text { Based on the } \\
\text { characteristics, } \\
\text { classify the } \\
\text { system/signal as } \\
\text { continuous- } \\
\text { discrete-time, linear } \\
\text { or nonlinear, time- } \\
\text { invariant or time- } \\
\text { varying, digital or } \\
\text { analog, periodic or } \\
\text { aperiodic, } \\
\text { deterministic or } \\
\text { probabilistic, causal } \\
\text { or non-causal and }\end{array}$ & $\begin{array}{l}\text { Based on the } \\
\text { characteristics, classify } \\
\text { the system/signal as } \\
\text { continuous- or discrete- } \\
\text { time, linear or } \\
\text { nonlinear, } \\
\text { invariant or time- } \\
\text { varying, digital or } \\
\text { analog, periodic or } \\
\text { aperiodic, deterministic } \\
\text { or probabilistic, causal } \\
\text { or non-causal and } \\
\text { energy or power using } \\
\text { explanation for logical }\end{array}$ & $\begin{array}{l}\text { Based on the } \\
\text { characteristics, unable } \\
\text { to properly classify } \\
\text { the system/signal as } \\
\text { continuous- or } \\
\text { discrete-time, linear or } \\
\text { nonlinear, time- } \\
\text { invariant or time- } \\
\text { varying, digital or } \\
\text { analog, periodic or } \\
\text { aperiodic, } \\
\text { deterministic or } \\
\text { probabilistic, causal or } \\
\text { non-causal and energy }\end{array}$ \\
\hline
\end{tabular}




\begin{tabular}{|c|c|c|c|}
\hline 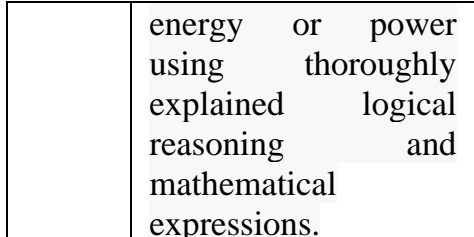 & $\begin{array}{lrr}\text { energy or } & \text { power } \\
\text { using } & \text { adequately } \\
\text { explained } & \text { logical } \\
\text { reasoning } & \text { and } \\
\text { mathematical } & \\
\text { expressions. } & \\
& \end{array}$ & $\begin{array}{l}\text { reasoning and } \\
\text { mathematical } \\
\text { expressions that } \\
\text { contains some errors. }\end{array}$ & $\begin{array}{l}\text { or power using } \\
\text { explanation for logical } \\
\text { reasoning and } \\
\text { mathematical } \\
\text { expressions. }\end{array}$ \\
\hline
\end{tabular}

\subsubsection{Rubrics for [CO-4_SO-11_PI-40]}

\begin{tabular}{|c|c|}
\hline Course Outcome & $\begin{array}{l}\text { CO-4: Determine LTI system response by applying the convolution } \\
\text { sum and convolution integral techniques. }\end{array}$ \\
\hline ABET Student Outcome & $\begin{array}{l}\text { SO-11: an ability to use the techniques, skills, and modern } \\
\text { engineering tools necessary for engineering practice }\end{array}$ \\
\hline Performance Indicator & $\begin{array}{l}\text { P1-40: Determine LTI system response by performing convolution } \\
\text { sum and convolution integral techniques based upon the type of input } \\
\text { signal. }\end{array}$ \\
\hline $\begin{array}{l}\text { Highest Expectation Student } \\
\text { Activity (Sequential with All } \\
\text { Gradable Major Steps) }\end{array}$ & $\begin{array}{l}\text { 1. Draw and properly label the input and impulse response signals } \\
\text { presented by the equation in the question. } \\
\text { 2. Write all the steps correctly using convolution technique (able to } \\
\text { draw correctly all the corresponding input and impulse response } \\
\text { signals with proper labelling) to find the corresponding output on } \\
\text { all the instants of time where output exists } \\
\text { 3. The output signal is drawn correctly and properly labelled with } \\
\text { respect to amplitude and time-axis. }\end{array}$ \\
\hline
\end{tabular}

\begin{tabular}{|c|c|c|c|c|}
\hline Score & $\begin{array}{l}\text { Excellent } \\
100 \%)\end{array}$ & Adequate $(75-89 \%)$ & Minimal (60-75\%) & $\begin{array}{l}\text { Unsatisfactory } \\
60 \%)\end{array}$ \\
\hline $10 \%$ & $\begin{array}{l}\text { Draw and properly } \\
\text { label the input and } \\
\text { impulse response } \\
\text { signals presented by } \\
\text { the equation in the } \\
\text { question. }\end{array}$ & $\begin{array}{l}\text { Draw and properly } \\
\text { label the input and } \\
\text { impulse response } \\
\text { signals presented by } \\
\text { the equation in the } \\
\text { question. }\end{array}$ & $\begin{array}{l}\text { Draw and properly label } \\
\text { the input and impulse } \\
\text { response signals } \\
\text { presented by the equation } \\
\text { in the question. }\end{array}$ & $\begin{array}{l}\text { Unable to draw and } \\
\text { properly label the } \\
\text { input and impulse } \\
\text { response signals } \\
\text { presented by the } \\
\text { equation in the } \\
\text { question. }\end{array}$ \\
\hline $70 \%$ & $\begin{array}{l}\text { Write all the steps } \\
\text { correctly using } \\
\text { convolution } \\
\text { technique (able to } \\
\text { draw correctly all } \\
\text { the corresponding } \\
\text { input and impulse } \\
\text { response signals } \\
\text { with proper } \\
\text { labeling) to find the } \\
\text { corresponding } \\
\text { output on all the } \\
\text { instants of time } \\
\text { where output exists. }\end{array}$ & $\begin{array}{l}\text { Write majority of the } \\
\text { steps correctly using } \\
\text { convolution } \\
\text { technique (able to } \\
\text { draw to draw } \\
\text { correctly majority of } \\
\text { the corresponding } \\
\text { input and impulse } \\
\text { response signals in } \\
\text { case of convolution } \\
\text { Sum) to find the } \\
\text { corresponding output } \\
\text { at majority of the } \\
\text { time instants where } \\
\text { output exists. }\end{array}$ & $\begin{array}{l}\text { Write some of the steps } \\
\text { correctly using } \\
\text { convolution technique } \\
\text { (able to draw to correctly } \\
\text { only some of the } \\
\text { corresponding input and } \\
\text { impulse response signals } \\
\text { in case of convolution } \\
\text { Sum) to find the } \\
\text { corresponding output at } \\
\text { some instants of the time } \\
\text { where output exists. }\end{array}$ & $\begin{array}{l}\text { Unable to write } \\
\text { correctly majority of } \\
\text { the steps using } \\
\text { convolution technique } \\
\text { (Unable to draw } \\
\text { correctly majority of } \\
\text { the corresponding } \\
\text { input and impulse } \\
\text { response signals in } \\
\text { case of convolution } \\
\text { Sum) to find the } \\
\text { corresponding output } \\
\text { at each instant of time } \\
\text { where output exists. }\end{array}$ \\
\hline $20 \%$ & $\begin{array}{l}\text { The output signal is } \\
\text { drawn correctly and } \\
\text { properly labelled } \\
\text { with respect to } \\
\text { amplitude and time- } \\
\text { axis. }\end{array}$ & $\begin{array}{l}\text { Majority of the } \\
\text { output signal is } \\
\text { drawn correctly and } \\
\text { properly labelled with } \\
\text { respect to amplitude } \\
\text { and time-axis. }\end{array}$ & $\begin{array}{l}\text { Some of the output } \\
\text { signal is drawn correctly } \\
\text { and properly labelled } \\
\text { with respect to amplitude } \\
\text { and time-axis. }\end{array}$ & $\begin{array}{l}\text { Majority of the output } \\
\text { signal is drawn } \\
\text { incorrectly and not } \\
\text { properly labelled with } \\
\text { respect to amplitude } \\
\text { and time-axis }\end{array}$ \\
\hline
\end{tabular}




\subsubsection{Rubrics for [CO-5_SO-11_PI-38]}

\begin{tabular}{|l|l|}
\hline Course Outcome & $\begin{array}{l}\text { CO-5: Analyze LTI systems based on their impulse response; find the } \\
\text { various characteristics of LTI systems such as causal/non-causal, } \\
\text { memory less/with memory, stability etc. }\end{array}$ \\
\hline ABET Student Outcome & $\begin{array}{l}\text { SO-11: an ability to use the techniques, skills, and modern engineering } \\
\text { tools necessary for engineering practice }\end{array}$ \\
\hline Performance Indicator & $\begin{array}{l}\text { P1-38: Analyze LTI systems based on their impulse response; find the } \\
\text { various characteristics of LTI systems such as causal/non-causal, } \\
\text { memory less/with memory, stability etc. }\end{array}$ \\
\hline $\begin{array}{l}\text { Highest Expectation Student } \\
\text { Activity (Sequential with All } \\
\text { Gradable Major Steps) }\end{array}$ & $\begin{array}{l}\text { 1. Identify the characteristics of the given impulse response of the } \\
\text { system. }\end{array}$ \\
2. $\begin{array}{l}\text { Based on the characteristics of the impulse response, analyze the } \\
\text { LTI system accurately in terms of system with or without } \\
\text { memory, Invertible or noninvertible, causal or non-causal, stable } \\
\text { or unstable etc using thoroughly explained logical reasoning and } \\
\text { mathematical expressions. }\end{array}$ \\
\hline
\end{tabular}

\begin{tabular}{|c|c|c|c|c|}
\hline Score & Excellent (90-100\%) & Adequate $(75-89 \%)$ & Minimal (60-75\%) & $\begin{array}{l}\text { Unsatisfactory } \\
60 \%)\end{array}$ \\
\hline $30 \%$ & 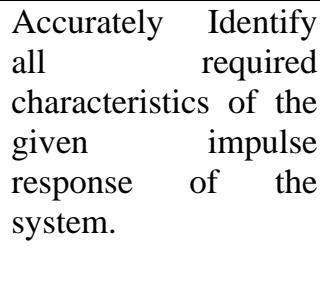 & $\begin{array}{l}\text { Accurately Identify } \\
\text { most of the required } \\
\text { characteristics of the } \\
\text { given impulse } \\
\text { response of the } \\
\text { system. }\end{array}$ & $\begin{array}{l}\text { Accurately } \\
\text { some of the required } \\
\text { characteristics of the } \\
\text { given impulse response } \\
\text { of the system. }\end{array}$ & $\begin{array}{l}\text { Major errors to } \\
\text { identify most of the } \\
\text { required } \\
\text { characteristics of the } \\
\text { given impulse } \\
\text { response of the } \\
\text { system. }\end{array}$ \\
\hline $70 \%$ & $\begin{array}{l}\text { Based on the } \\
\text { characteristics of the } \\
\text { impulse response, } \\
\text { classify the LTI } \\
\text { system accurately } \\
\text { with respect to the } \\
\text { system being with or } \\
\text { without memory, } \\
\text { Invertible or } \\
\text { noninvertible, causal } \\
\text { or non-causal, stable } \\
\text { or unstable etc. using } \\
\text { thoroughly explained } \\
\text { logical reasoning and } \\
\text { mathematical } \\
\text { expressions. }\end{array}$ & $\begin{array}{l}\text { Based on the } \\
\text { characteristics of the } \\
\text { impulse response, } \\
\text { classify the LTI } \\
\text { system accurately } \\
\text { with respect to the } \\
\text { system being with or } \\
\text { without memory, } \\
\text { Invertible or } \\
\text { noninvertible, causal } \\
\text { or non-causal, stable } \\
\text { or unstable etc. using } \\
\text { adequately explained } \\
\text { logical reasoning and } \\
\text { mathematical } \\
\text { expressions. }\end{array}$ & $\begin{array}{l}\text { Based on the } \\
\text { characteristics of the } \\
\text { impulse response, } \\
\text { classify the LTI system } \\
\text { accurately with respect } \\
\text { to the system being with } \\
\text { or without memory, } \\
\text { Invertible or } \\
\text { noninvertible, causal or } \\
\text { non-causal, stable or } \\
\text { unstable etc. using } \\
\text { explanation for logical } \\
\text { reasoning and } \\
\text { mathematical that } \\
\text { expressions } \\
\text { contains some errors. }\end{array}$ & $\begin{array}{l}\text { Based on the } \\
\text { characteristics of the } \\
\text { impulse response, } \\
\text { unable to properly } \\
\text { classify the LTI } \\
\text { system accurately with } \\
\text { respect to the system } \\
\text { being with or without } \\
\text { memory, Invertible or } \\
\text { noninvertible, causal } \\
\text { or non-causal, stable } \\
\text { or unstable etc. using } \\
\text { explanation for logical } \\
\text { reasoning and } \\
\text { mathematical } \\
\text { expressions. }\end{array}$ \\
\hline
\end{tabular}

\subsubsection{Rubrics for [CO-6_SO-11_PI-37]}

\begin{tabular}{|l|l|}
\hline Course Outcome & $\begin{array}{l}\text { CO-6: Characterize LTI systems by representing their differential and } \\
\text { difference equations using block diagrams. }\end{array}$ \\
\hline ABET Student Outcome & $\begin{array}{l}\text { SO-11: an ability to use the techniques, skills, and modern engineering } \\
\text { tools necessary for engineering practice }\end{array}$ \\
\hline Performance Indicator & $\begin{array}{l}\text { P1-37: Use given differential (continuous time) and difference } \\
\text { (discrete time) equations to obtain the block diagram representation of } \\
\text { an LTI system; solve these equations using given parameters to find } \\
\text { the explicit relationship between input and output. }\end{array}$ \\
\hline
\end{tabular}




\begin{tabular}{|l|l|}
\hline Highest Expectation Student & 1. $\begin{array}{l}\text { For an LTI system whose Implicit relationship between the inputs } \\
\text { activity (Sequential with All }\end{array}$ \\
Gradable Major Steps) & $\begin{array}{l}\text { differential/difference equation, solve it to find the explicit } \\
\text { relationship between output and input } \\
\text { recursive/nonrecursive solution. }\end{array}$ \\
2. $\begin{array}{l}\text { Use given auxiliary conditions to have exact relationship between } \\
\text { input and output. } \\
\text { And/or draw block diagram of the given LTI systems represented } \\
\text { by differential/difference equation. }\end{array}$
\end{tabular}

\begin{tabular}{|c|c|c|c|c|}
\hline Score & Excellent (90-100\%) & Adequate $(75-89 \%)$ & Minimal (60-75\%) & Unsatisfactory $(0-60 \%)$ \\
\hline $50 \%$ & $\begin{array}{l}\text { For an LTI system } \\
\text { whose Implicit } \\
\text { relationship between } \\
\text { the inputs and outputs } \\
\text { are given by the } \\
\text { linear constant- } \\
\text { coefficient } \\
\text { differential/difference } \\
\text { equation, solve it to } \\
\text { find accurately the } \\
\text { explicit relationship } \\
\text { between output and } \\
\text { input using recursive } \\
\text { / nonrecursive } \\
\text { solution. }\end{array}$ & $\begin{array}{l}\text { For an LTI system } \\
\text { whose Implicit } \\
\text { relationship between } \\
\text { the inputs and outputs } \\
\text { are given by the } \\
\text { linear constant- } \\
\text { coefficient } \\
\text { differential/difference } \\
\text { equation, solve with } \\
\text { minor errors the } \\
\text { explicit relationship } \\
\text { between output and } \\
\text { input using recursive } \\
\text { / nonrecursive } \\
\text { solution. }\end{array}$ & $\begin{array}{l}\text { For an LTI system } \\
\text { whose } \\
\text { relationship between } \\
\text { the inputs and outputs } \\
\text { are given by the linear } \\
\text { constant-coefficient } \\
\text { differential/difference } \\
\text { equation, solve with } \\
\text { minor errors the } \\
\text { explicit relationship } \\
\text { between output and } \\
\text { input using } \\
\text { recursive/nonrecursive } \\
\text { solution. }\end{array}$ & $\begin{array}{l}\text { For an LTI system } \\
\text { whose Implicit } \\
\text { relationship between } \\
\text { the inputs and outputs } \\
\text { are given by the linear } \\
\text { constant-coefficient } \\
\text { differential/difference } \\
\text { equation, solve with } \\
\text { major errors the } \\
\text { explicit relationship } \\
\text { between output and } \\
\text { input using recursive / } \\
\text { nonrecursive solution. }\end{array}$ \\
\hline $20 \%$ & $\begin{array}{l}\text { Use given auxiliary } \\
\text { conditions accurately } \\
\text { to have exact } \\
\text { relationship between } \\
\text { input and output. }\end{array}$ & $\begin{array}{l}\text { Use given auxiliary } \\
\text { conditions accurately } \\
\text { to have exact } \\
\text { relationship between } \\
\text { input and output. }\end{array}$ & $\begin{array}{l}\text { Use given auxiliary } \\
\text { conditions to have } \\
\text { exact relationship } \\
\text { between input and } \\
\text { output with minor } \\
\text { errors. }\end{array}$ & $\begin{array}{l}\text { Use given auxiliary } \\
\text { conditions to have } \\
\text { exact relationship } \\
\text { between input and } \\
\text { output with major } \\
\text { errors. }\end{array}$ \\
\hline $30 \%$ & $\begin{array}{l}\text { And/or accurately } \\
\text { draw block diagram } \\
\text { of the given LTI } \\
\text { systems represented } \\
\text { by } \\
\text { differential/difference } \\
\text { equation. }\end{array}$ & $\begin{array}{l}\text { And/or draw block } \\
\text { diagram with minor } \\
\text { errors of the given } \\
\text { LTI systems } \\
\text { represented by } \\
\text { differential/difference } \\
\text { equation. }\end{array}$ & $\begin{array}{l}\text { And/or draw block } \\
\text { diagram with minor } \\
\text { errors of the given LTI } \\
\text { systems represented by } \\
\text { differential/difference } \\
\text { equation. }\end{array}$ & $\begin{array}{l}\text { And/or draw block } \\
\text { diagram with major } \\
\text { errors of the given LTI } \\
\text { systems represented by } \\
\text { differential/difference } \\
\text { equation. }\end{array}$ \\
\hline
\end{tabular}

\subsubsection{Rubrics for [CO-7_SO-11_PI-53]}

\begin{tabular}{|c|c|c|c|}
\hline Course Outcome & \multicolumn{3}{|c|}{$\begin{array}{l}\text { CO-7: Apply the Fourier series for analyzing the frequency spectrum } \\
\text { of periodic signals. }\end{array}$} \\
\hline ABET Student Outcome & \multicolumn{3}{|c|}{$\begin{array}{l}\text { SO-11: an ability to use the techniques, skills, and modern engineering } \\
\text { tools necessary for engineering practice }\end{array}$} \\
\hline Performance Indicator & \multicolumn{3}{|c|}{$\begin{array}{l}\text { P1-53: Analyze the frequency spectrum of periodic CT/DT signals by } \\
\text { applying Fourier series and obtain the coefficients of constituent } \\
\text { signals; or use given coefficients of harmonically related constituent } \\
\text { basic signals to reconstruct the periodic signal. }\end{array}$} \\
\hline $\begin{array}{l}\text { Highest Expectation Student } \\
\text { Activity (Sequential with All } \\
\text { Gradable Major Steps) }\end{array}$ & $\begin{array}{l}\text { 1. Examine tl } \\
\text { fundamenta } \\
\text { Fourier seri } \\
\text { periodic CT } \\
\text { 2. Simplify th } \\
\text { OR the time }\end{array}$ & $\begin{array}{l}\text { given periodic CT/ } \\
\text { equency OR Substitu } \\
\text { o obtain the detailed } \\
\Gamma \text { signal } \\
\text { etailed exponential } \\
\text { main representation }\end{array}$ & $\begin{array}{l}\text { ignal to determine the } \\
\text { coefficients of the given } \\
\text { nential form of the given } \\
\text { to obtain the coefficients } \\
\text { CT/DT periodic signal }\end{array}$ \\
\hline \begin{tabular}{l|l} 
Score & Excellent $(90-100 \%)$
\end{tabular} & Adequate $(75-89 \%)$ & Minimal (60-75\%) & Unsatisfactory $(0-60 \%)$ \\
\hline
\end{tabular}




\begin{tabular}{|c|c|c|c|c|}
\hline \multirow[t]{2}{*}{$40 \%$} & $\begin{array}{l}\text { Examine the given } \\
\text { periodic CT/DT } \\
\text { signal to determine } \\
\text { the fundamental }\end{array}$ & $\begin{array}{l}\text { Examine the given } \\
\text { periodic } \mathrm{CT} / \mathrm{DT} \\
\text { signal to determine } \\
\text { the fundamental }\end{array}$ & $\begin{array}{l}\text { Examine the given } \\
\text { periodic CT/DT signal } \\
\text { to determine the } \\
\text { fundamental frequency }\end{array}$ & $\begin{array}{l}\text { Examine the given } \\
\text { periodic CT/DT signal } \\
\text { to determine the } \\
\text { fundamental frequency }\end{array}$ \\
\hline & $\begin{array}{l}\text { frequency } \\
\text { Substitute the } \\
\text { coefficients of the } \\
\text { given Fourier series } \\
\text { to accurately obtain } \\
\text { the detailed } \\
\text { exponential form of } \\
\text { the given periodic } \\
\text { CT/DT signal. }\end{array}$ & $\begin{array}{l}\text { frequency } \\
\text { Substitute the } \\
\text { coefficients of the } \\
\text { given Fourier series } \\
\text { to accurately obtain } \\
\text { the detailed } \\
\text { exponential form of } \\
\text { the given periodic } \\
\text { CT/DT signal. }\end{array}$ & $\begin{array}{l}\text { OR Substitute the } \\
\text { coefficients of the } \\
\text { given Fourier series to } \\
\text { obtain with minor } \\
\text { errors the detailed } \\
\text { exponential form of the } \\
\text { given periodic CT/DT } \\
\text { signal. }\end{array}$ & $\begin{array}{l}\text { OR Substitute the } \\
\text { coefficients of the } \\
\text { given Fourier series to } \\
\text { obtain with major } \\
\text { errors the detailed } \\
\text { exponential form of the } \\
\text { given periodic CT/DT } \\
\text { signal. }\end{array}$ \\
\hline $60 \%$ & $\begin{array}{l}\text { Simplify the detailed } \\
\text { exponential form to } \\
\text { accurately obtain the } \\
\text { coefficients OR the } \\
\text { time domain } \\
\text { representation of the } \\
\text { CT/DT periodic } \\
\text { signal. }\end{array}$ & $\begin{array}{l}\text { Simplify the detailed } \\
\text { exponential form to } \\
\text { obtain with minor } \\
\text { error the coefficients } \\
\text { OR the time domain } \\
\text { representation of the } \\
\text { CT/DT periodic } \\
\text { signal. }\end{array}$ & $\begin{array}{l}\text { Simplify the detailed } \\
\text { exponential form to } \\
\text { obtain with minor } \\
\text { errors the coefficients } \\
\text { OR the time domain } \\
\text { representation of the } \\
\text { CT/DT periodic signal. }\end{array}$ & $\begin{array}{l}\text { Simplify the detailed } \\
\text { exponential form to } \\
\text { obtain with major } \\
\text { errors the coefficients } \\
\text { OR the time domain } \\
\text { representation of the } \\
\text { CT/DT periodic signal. }\end{array}$ \\
\hline
\end{tabular}

\subsubsection{Rubrics for [CO-8_SO-11_PI-54]}

\begin{tabular}{|c|c|}
\hline Course Outcome & $\begin{array}{l}\text { CO-8: Apply continuous-time and discrete-time Fourier transform for } \\
\text { analyzing the frequency spectrum of periodic and aperiodic signals. }\end{array}$ \\
\hline ABET Student Outcome & $\begin{array}{l}\text { SO-11: an ability to use the techniques, skills, and modern engineering } \\
\text { tools necessary for engineering practice }\end{array}$ \\
\hline Performance Indicator & $\begin{array}{l}\text { P1-54: Analyze the frequency spectrum of periodic and aperiodic } \\
\text { CT/DT signals by applying Fourier transform; convert given signal in } \\
\text { frequency domain to time domain using inverse Fourier transform. }\end{array}$ \\
\hline $\begin{array}{l}\text { Highest Expectation Student } \\
\text { Activity (Sequential with All } \\
\text { Gradable Major Steps) }\end{array}$ & $\begin{array}{l}\text { 1. Examine the given form to identify in terms of time- } \\
\text { domain/frequency-domain signal, periodic/aperiodic signal and } \\
\text { CT/DT signal for correctly applying the corresponding technique } \\
\text { /equation. } \\
\text { 2. Find the corresponding values OR insert the values in the } \\
\text { corresponding equation to accurately obtain the required form. }\end{array}$ \\
\hline
\end{tabular}

\begin{tabular}{|c|c|c|c|c|}
\hline Score & $\begin{array}{l}\text { Excellent } \\
100 \%)\end{array}$ & Adequate $(75-89 \%)$ & Minimal (60-75\%) & $\begin{array}{l}\text { Unsatisfactory } \\
60 \%)\end{array}$ \\
\hline $20 \%$ & $\begin{array}{l}\text { Examine the given } \\
\text { form of the signal } \\
\text { to identify in terms } \\
\text { of time- } \\
\text { domain/frequency- } \\
\text { domain, } \\
\text { periodic/aperiodic } \\
\text { and CT/DT signal } \\
\text { for accurately } \\
\text { applying the } \\
\text { corresponding } \\
\text { technique /equation. }\end{array}$ & $\begin{array}{l}\text { Examine the given } \\
\text { form of the signal to } \\
\text { identify in terms of } \\
\text { time- } \\
\text { domain/frequency- } \\
\text { domain, } \\
\text { periodic/aperiodic } \\
\text { signal and CT/DT } \\
\text { signal for accurately } \\
\text { applying the } \\
\text { corresponding } \\
\text { technique /equation. }\end{array}$ & $\begin{array}{l}\text { Examine the given } \\
\text { form of the signal to } \\
\text { identify in terms of } \\
\text { time- } \\
\text { domain/frequency- } \\
\text { domain signal, } \\
\text { periodic/aperiodic } \\
\text { signal and CT/DT } \\
\text { signal for applying with } \\
\text { minor error the } \\
\text { corresponding } \\
\text { technique /equation. }\end{array}$ & $\begin{array}{l}\text { Examine the given } \\
\text { form of the signal to } \\
\text { identify in terms of } \\
\text { time- } \\
\text { domain/frequency- } \\
\text { domain, } \\
\text { periodic/aperiodic and } \\
\text { CT/DT for applying } \\
\text { with major error the } \\
\text { corresponding } \\
\text { technique /equation. }\end{array}$ \\
\hline
\end{tabular}




\begin{tabular}{|c|c|c|c|c|}
\hline $80 \%$ & $\begin{array}{l}\text { Find the } \\
\text { corresponding } \\
\text { values OR insert the } \\
\text { values in the } \\
\text { corresponding } \\
\text { equation to } \\
\text { correctly obtain the } \\
\text { required form / } \\
\text { result. }\end{array}$ & $\begin{array}{l}\text { Find the corresponding } \\
\text { values OR insert the } \\
\text { values in the } \\
\text { corresponding equation } \\
\text { to obtain with minor } \\
\text { errors the required } \\
\text { form / result. }\end{array}$ & $\begin{array}{l}\text { Find the corresponding } \\
\text { values OR insert the } \\
\text { values in the } \\
\text { corresponding equation } \\
\text { to obtain with minor } \\
\text { errors the required form } \\
\text { / result. }\end{array}$ & $\begin{array}{l}\text { Find the corresponding } \\
\text { values OR insert the } \\
\text { values in the } \\
\text { corresponding } \\
\text { equation to obtain with } \\
\text { major errors the } \\
\text { required form / result. }\end{array}$ \\
\hline
\end{tabular}

2.2.9 Rubrics for [CO-9_SO-9_PI-12]

\begin{tabular}{|l|l|}
\hline Course Outcome & $\begin{array}{l}\text { CO-9: Conduct research to study and examine the real-life applications } \\
\text { of convolution techniques, Fourier series and Fourier transform. }\end{array}$ \\
\hline ABET Student Outcome & $\begin{array}{l}\text { SO-9: a recognition of the need for, and an ability to engage in life- } \\
\text { long learning }\end{array}$ \\
\hline Performance Indicator & $\begin{array}{l}\text { P1-12: Perform literature survey on given engineering } \\
\text { problem/application; Locate requested technical information using the } \\
\text { internet, company provided or external resources; provide professional } \\
\text { research citations for technical information relevant to the topic of } \\
\text { research; assimilate technical information in an organized format for } \\
\text { presenting the practicality of application of engineering solutions to } \\
\text { existing problems. }\end{array}$ \\
\hline $\begin{array}{l}\text { Highest Expectation Student } \\
\text { Activity (Sequential with All } \\
\text { Gradable Major Steps) }\end{array}$ & $\begin{array}{l}\text { 1. Locate and gather relevant information by utilizing multiple sources } \\
\text { sheets, news article, technical magazines etc. } \\
\text { s. Assimilate relevant information in all topics such as: } \\
\text { (i) Background of engineering problems, }\end{array}$ \\
$\begin{array}{l}\text { (ii) contemporary solutions, } \\
\text { (iii) limitations/issues of contemporary solutions } \\
\text { 3. Accurately provide appropriate and complete list of references }\end{array}$ \\
\hline
\end{tabular}

\begin{tabular}{|c|c|c|c|c|}
\hline Score & Excellent (90-100\%) & Adequate $(75-89 \%)$ & Minimal (60-75\%) & Unsatisfactory $(0-60 \%)$ \\
\hline $40 \%$ & $\begin{array}{l}\text { Locate and gather } \\
\text { relevant information } \\
\text { by utilizing multiple } \\
\text { sources such as } \\
\text { library, } \\
\text { manufacturer web, } \\
\text { catalogue } \\
\text { engineering data } \\
\text { sheets, news article, } \\
\text { technical magazines } \\
\text { etc.; }\end{array}$ & $\begin{array}{l}\text { Locate and gather } \\
\text { relevant information by } \\
\text { utilizing at least two } \\
\text { sources such as library, } \\
\text { web, manufacturer } \\
\text { catalogue or } \\
\text { engineering data } \\
\text { sheets, news article, } \\
\text { technical magazines } \\
\text { etc.; } \\
\text { AND/OR }\end{array}$ & $\begin{array}{l}\text { Locate and gather } \\
\text { relevant information } \\
\text { by utilizing at least } \\
\text { one source such as } \\
\text { library, web, } \\
\text { manufacturer } \\
\text { catalogue or } \\
\text { engineering data } \\
\text { sheets, news article, } \\
\text { technical magazines } \\
\text { etc.; } \\
\text { AND/OR }\end{array}$ & $\begin{array}{l}\text { Unable to locate and } \\
\text { gather relevant } \\
\text { information by utilizing } \\
\text { at least one source such } \\
\text { as library, web, } \\
\text { manufacturer catalogue } \\
\text { or engineering data } \\
\text { sheets, news article, } \\
\text { technical magazines } \\
\text { etc.; } \\
\text { AND/OR }\end{array}$ \\
\hline $50 \%$ & $\begin{array}{l}\text { Assimilate relevant } \\
\text { information in all } \\
\text { topics such as: } \\
\text { (i) Background of } \\
\text { engineering } \\
\text { problems, } \\
\text { (ii) contemporary } \\
\text { solutions, } \\
\text { (iii) limitations/issues } \\
\text { of contemporary } \\
\text { solutions }\end{array}$ & $\begin{array}{l}\text { Assimilate relevant } \\
\text { information in three } \\
\text { topics such as: } \\
\text { (i) Background of } \\
\text { engineering problems, } \\
\text { (ii) contemporary } \\
\text { solutions, } \\
\text { (iii) limitations/issues } \\
\text { of contemporary } \\
\text { solutions } \\
\text { AND/OR }\end{array}$ & $\begin{array}{l}\text { Assimilate relevant } \\
\text { information in two } \\
\text { topics such as: } \\
\text { (i) Background of } \\
\text { engineering } \\
\text { problems, } \\
\text { (ii) contemporary } \\
\text { solutions, } \\
\text { (iii) limitations/issues } \\
\text { of contemporary } \\
\text { solutions } \\
\text { AND/OR }\end{array}$ & $\begin{array}{l}\text { Unable to assimilate } \\
\text { relevant information in } \\
\text { two topics such as: } \\
\text { (i) Background of } \\
\text { engineering problems, } \\
\text { (ii) contemporary } \\
\text { solutions, } \\
\text { (iii) limitations/issues } \\
\text { of contemporary } \\
\text { solutions } \\
\text { AND/OR }\end{array}$ \\
\hline
\end{tabular}




\begin{tabular}{|c|c|c|c|c|c|}
\hline $10 \%$ & $\begin{array}{l}\text { Accurately } \\
\text { appropriate } \\
\text { complete } \\
\text { references }\end{array}$ & $\begin{array}{r}\text { provide } \\
\text { and } \\
\text { list of }\end{array}$ & $\begin{array}{l}\text { Minor deficiency in } \\
\text { providing appropriate } \\
\text { and complete list of } \\
\text { references }\end{array}$ & $\begin{array}{l}\text { Minor deficiency in } \\
\text { providing appropriate } \\
\text { and complete list of } \\
\text { references }\end{array}$ & $\begin{array}{l}\text { Major deficiency in } \\
\text { providing appropriate } \\
\text { and complete list of } \\
\text { references }\end{array}$ \\
\hline
\end{tabular}

\subsubsection{Rubrics for [CO-10_SO-11_PI-61]}

\begin{tabular}{|c|c|c|c|c|}
\hline \multicolumn{2}{|c|}{ Course Outcome } & \multicolumn{3}{|c|}{$\begin{array}{l}\text { CO-10: Apply Z-transform, inverse Z-Transform and its properties for } \\
\text { the analysis of LTI systems. }\end{array}$} \\
\hline \multicolumn{2}{|c|}{ ABET Student Outcome } & \multicolumn{3}{|c|}{$\begin{array}{l}\text { SO-11: an ability to use the techniques, skills, and modern engineering } \\
\text { tools necessary for engineering practice }\end{array}$} \\
\hline \multicolumn{2}{|c|}{ Performance Indicator } & \multicolumn{3}{|c|}{$\begin{array}{l}\text { P1-61: Analyze LTI systems by applying Z-transform, inverse Z- } \\
\text { transform and its properties; obtain Z-transform of the given signal; } \\
\text { draw the region of convergence; find its poles and zeros; or use inverse } \\
\text { Z-transform to obtain the time domain signal. }\end{array}$} \\
\hline \multicolumn{2}{|c|}{$\begin{array}{l}\text { Highest Expectation Student } \\
\text { Activity (Sequential with All } \\
\text { Gradable Major Steps) }\end{array}$} & \multicolumn{3}{|c|}{$\begin{array}{l}\text { 1. Determine accurately the z-transform or inverse z-transform of the } \\
\text { given sequence and/or accurately find the region of convergence } \\
\text { (ROC). } \\
\text { 2. Find system poles and system zeros of the given sequence } \\
\text { accurately and accurately sketch pole-zero plot and indicate the } \\
\text { region of convergence in the plot. } \\
\text { 3. Indicate accurately whether Fourier Transform of the sequence } \\
\text { exists using logical reasoning. }\end{array}$} \\
\hline Score & Excellent (90-100\%) & Adequate $(75-89 \%)$ & Minimal (60-75\%) & Unsatisfactory $(0-60 \%)$ \\
\hline $50 \%$ & $\begin{array}{l}\text { Determine accurately } \\
\text { the z-transform or } \\
\text { inverse z-transform } \\
\text { of the given sequence } \\
\text { and/or accurately find } \\
\text { the region of } \\
\text { convergence (ROC). } \\
\text { AND / OR }\end{array}$ & $\begin{array}{l}\text { Determine accurately } \\
\text { the z-transform or } \\
\text { inverse z-transform } \\
\text { of the given sequence } \\
\text { and/or accurately find } \\
\text { the region of } \\
\text { convergence (ROC). } \\
\text { AND / OR }\end{array}$ & $\begin{array}{l}\text { Determine the } \mathrm{z}- \\
\text { transform or inverse } \mathrm{z}- \\
\text { transform of the given } \\
\text { sequence with minor } \\
\text { errors and/or find the } \\
\text { region of convergence } \\
\text { (ROC) with minor } \\
\text { errors. } \\
\text { AND / OR }\end{array}$ & $\begin{array}{l}\text { Determine the } \mathrm{z}- \\
\text { transform or inverse } \mathrm{z}- \\
\text { transform of the given } \\
\text { sequence with major } \\
\text { errors and/or find the } \\
\text { region of convergence } \\
\text { (ROC) with major } \\
\text { errors. } \\
\text { AND / OR }\end{array}$ \\
\hline $40 \%$ & $\begin{array}{l}\text { Find system poles } \\
\text { and system zeros of } \\
\text { the given sequence } \\
\text { accurately and } \\
\text { accurately sketch } \\
\text { pole-zero plot and } \\
\text { indicate the region of } \\
\text { convergence in the } \\
\text { plot. } \\
\text { AND / OR }\end{array}$ & $\begin{array}{l}\text { Find system poles } \\
\text { and system zeros of } \\
\text { the given sequence } \\
\text { accurately and sketch } \\
\text { pole-zero plot and } \\
\text { indicate the region of } \\
\text { convergence in the } \\
\text { plot with minor } \\
\text { errors. } \\
\text { AND / OR }\end{array}$ & $\begin{array}{l}\text { Find system poles and } \\
\text { system zeros of the } \\
\text { given sequence with } \\
\text { minor errors and sketch } \\
\text { pole-zero plot and } \\
\text { indicate the region of } \\
\text { convergence in the plot } \\
\text { with minor errors. } \\
\text { AND / OR }\end{array}$ & $\begin{array}{l}\text { Find system poles and } \\
\text { system zeros of the } \\
\text { given sequence with } \\
\text { major errors and sketch } \\
\text { pole-zero plot and } \\
\text { indicate the region of } \\
\text { convergence in the plot } \\
\text { with major errors. } \\
\text { AND / OR }\end{array}$ \\
\hline $10 \%$ & $\begin{array}{l}\text { Indicate accurately } \\
\text { whether Fourier } \\
\text { Transform of the } \\
\text { sequence exists using } \\
\text { logical reasoning. }\end{array}$ & $\begin{array}{l}\text { Indicate accurately } \\
\text { and/or inaccurately } \\
\text { whether Fourier } \\
\text { Transform of the } \\
\text { sequence exists using } \\
\text { logical reasoning. }\end{array}$ & $\begin{array}{l}\text { Indicate accurately } \\
\text { and/or inaccurately } \\
\text { whether Fourier } \\
\text { Transform of the } \\
\text { sequence exists using } \\
\text { logical reasoning. }\end{array}$ & $\begin{array}{l}\text { Indicate accurately } \\
\text { and/or inaccurately } \\
\text { whether Fourier } \\
\text { Transform of the } \\
\text { sequence exists using } \\
\text { logical reasoning. }\end{array}$ \\
\hline
\end{tabular}

\section{Continuous Quality Improvement (CQI)}

\subsection{EAMU Performance Vector Calculation}

We have used customized web-based software 'EvalTools' from MAKTEAM Inc. [12, 14]. It has a

module for identifying an assignment with specific questions with relative high coverage of a certain PI mapping to $\mathrm{CO}$, and $\mathrm{SO}$ for EAMU calculation where EAMU is an abbreviation of 'Excellent', 'Adequate', 'Minimal', and 'Unsatisfactory'. It uses summative assessment by removing all the students 
receiving ' $\mathrm{DN}$ ', ' $\mathrm{F}$ ', ' $\mathrm{W}$ ' or ' $\mathrm{I}$ ' grades in a course from EAMU calculations, thus including only the scores in a selected assignment of the remaining students. It computes the weighted average percentage of the assessments for every student. Weights are put as per the product of the student's percentage in the course grading scale and multiplication factor depending on course format. It then utilizes average percentage for determining the no of students falling into the EAMU categories using the preselected assessment criteria. It then computes the EAMU average rating by scaling it to 5 for a weighted average based on a 3-point scale as shown in Eq. (1) [15].

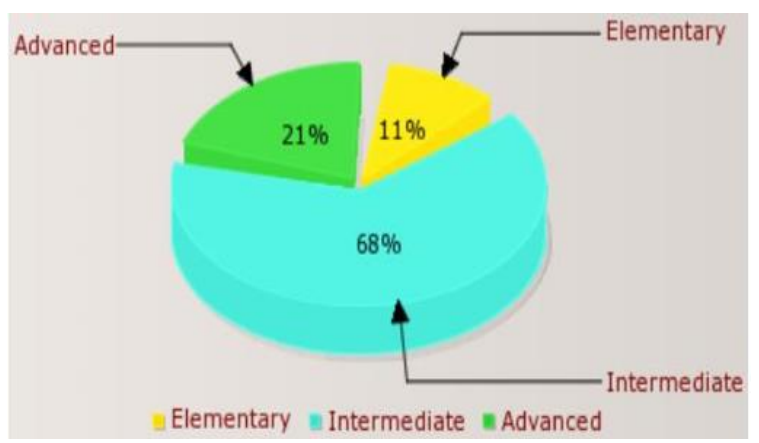

Figure 3. Percentage distribution coverage of threelevels skills of revised Bloom's taxonomy

EAMU Average $=\frac{3 \times E+2 \times A+1 \times M+0 \times U}{E+A+M+U} \times\left(\frac{5}{3}\right)$

The EAMU vector for each $\mathrm{CO}$ is attained by counting each student's EAMU classifications in which 'Excellent' category is the scores $>=90 \%$, similarly 'Adequate' has the scores range of $>=75 \%$ and $<90 \%$, 'Minimal': scores $>=60 \%$ and $<75 \%$ and Unsatisfactory: scores $<60 \%$. Finally, the average of the EAMU vector for each $\mathrm{CO}$ is attained after rescaling it to 5 .

\subsection{Course Outcomes Analysis for Fall- Semester}

Based on EAMU vector, the students' performance as per the course outcome of the course 'Signals and Systems' for Fall-semester of 2017-18 is shown in the histogram plot of Figure 4. The color-coded visual results show that students have failed to perform well in the COs 2, 5, 6, 7, 8 and 10 whereas the student's performance also needs improvement in CO 9. Figure 5 shows the ABET Student Outcomes coverage by different COs and their EAMU average for the course 'Signals and Systems' for the Fall-semester of 2017-18. Similarly, Figure 6 shows the histogram plot of student outcome's EAMU average based on 5-point scale for the Fall-semester of 2017-18. It is evident that the student's performance in $\mathrm{SO}_{-} 1$ and $\mathrm{SO}_{-} 11$ is poor, whereas the performance of students in the SO 9 also needs improvement.

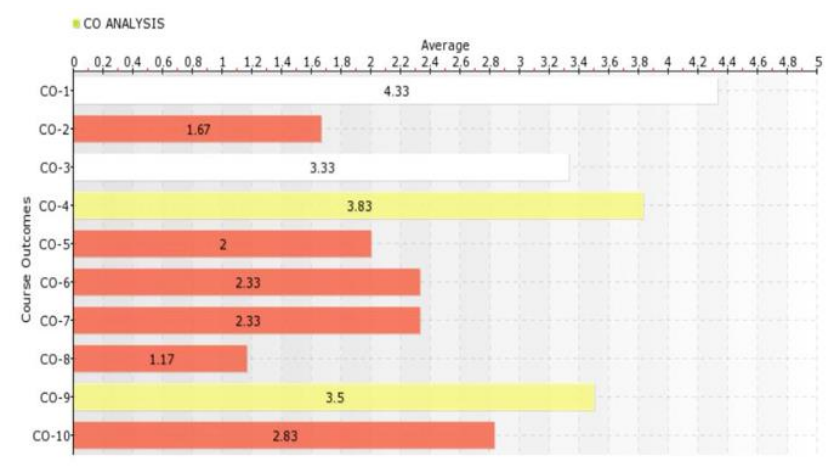

Figure 4. Course outcomes EAMU average based on 5-point scale for the Fall-semester of 2017-18

\begin{tabular}{|c|c|c|c|c|}
\hline Item & Student Outcomes & $\begin{array}{l}\text { Correlated } \\
\text { Course Outcomes }\end{array}$ & E A M U & Average \\
\hline SO_1 & $\begin{array}{l}\text { an ability to apply knowledge of mathematics, science, } \\
\text { and engineering }\end{array}$ & $\mathrm{CO} 1, \mathrm{CO} 2, \mathrm{CO} 3$ & 0201 & 3.11 \\
\hline $0 \_9$ & $\begin{array}{l}\text { a recognition of the need for, and an ability to engage in } \\
\text { life-long learning }\end{array}$ & $\mathrm{COS}$ & 0010 & 3.50 \\
\hline $0 \_1$ & $\begin{array}{l}\text { an ability to use the techniques, skills, and modern } \\
\text { engineering tools necessary for engineering practice }\end{array}$ & $\begin{array}{l}\mathrm{CO} 8, C 04, \mathrm{CO} 7, \\
\mathrm{CO} 6, \mathrm{CO} 10, \mathrm{CO} 5\end{array}$ & 0015 & 2.42 \\
\hline
\end{tabular}

Figure 5. Student outcomes coverage by different COs and their EAMU average

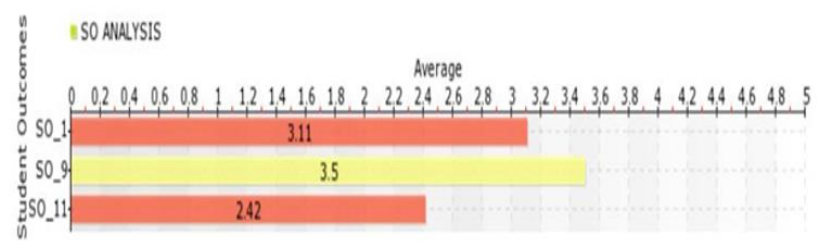

Figure 6. Student outcomes EAMU average based on 5-point scale for the Fall-Semester of 2017-18

\subsection{Modification in teaching and learning strategies}

The following teaching and learning strategies were adopted to make the students perform better in the failing course outcomes.

1. It is very important to see the background of students and their habits of learning and their interests and concerns. As students from different countries have different backgrounds and have different mind sets. And their approach towards learning is different. As per OBE, every student can learn, but the way and the time taken by him is different. In other words, all students can learn, but not at the same pace. Different interactive activities are performed in order to know about students. It has helped us to learn more about our students, their specific needs and finding out the ways the students feel more comfortable. 
2. Based on the response and feedback from the students, the lecture plans are changed accordingly. This has helped to create a nurturing and inclusive learning atmosphere where every student feels that he is there to learn.

3. Since English is not the mother language of Saudi students and almost all other students studying this course, they have a problem of understanding the lecture delivered in English. Also, most of the students don't start learning English from their 1st grade in school rather start it in their 4th grade or even later than that. That's why their learning process through lecture delivery in English is slow. This fact is taken into account and suggestions were made to the English Department for improving the English comprehension, writing and reading skills of the students. This fact is also considered in the lecture delivery and the lecture's pace is adjusted and feedback is constantly taken from the students in order to know that whether the students have grasped the given concepts.

4. It is also important to see the burden on the students as sometimes they are unable to perform well due to other parallel assignments or assessments related to other subjects going on, which affects their performance in a specific subject as they are unable to have sufficient time to prepare a specific assignment. This fact is taken into account at the department level and subsequent modifications are done on the assessment criteria related to subjects of electrical engineering to balance the load/burden on students.

5. To enable the students to represent diagrammatically the complex exponential and sinusoidal waveforms, the $\mathrm{CO} 2$ is added for enabling the students to have strong basics in signals of knowing the fundamental concepts about periodic signals such fundamental frequencies, the effects of change in frequency and change in phase shift so that they can use their solid base for the later course such communication systems, digital communication, and Mobile \& wireless communication etc. More related problems are solved in the class and then the students were given problems in the class to solve in the groups and ask questions accordingly to clear their concepts in this regard.

6. For enabling the students to perform better in $\mathrm{CO} 4$, the problem-based learning approach is used. It was observed during lecture delivery, that although the technique of convolution sum and convolution integral was properly elaborated, but even then, the student don't understand and grasp the concept until they solve it by themselves. Therefore, two strategies were adopted, i.e. To elaborate the technique during the lecture, the students are asked to solve the full problem or part of it, so that they grasp the concept and clear their concepts if they have problems in solving it. Secondly the students are given homework to practice the problems at home.
However, it was not helping it as the students were copying the homework from one another. Therefore, the tutorial sessions were conducted, and students were asked to solve the homework problems in that tutorial session. This has helped a lot and improved students' performance significantly.

7. With regards to the poor performance of the students in $\mathrm{CO} 5$, it is observed that students got confused and mixed it with the $\mathrm{CO} 3$. The $\mathrm{CO} 3$ relates to classification of systems into different categories based on the relationship between input and output of the system, whereas the CO5 is evaluation/classifications of systems based on their impulse responses. This fact is taken into account and is added in lecture delivery to clarify the differences between $\mathrm{CO} 3$ and $\mathrm{CO} 5$ so that they can perform well in both COs

8. With reference to $\mathrm{CO} 6$, the student performance is analyzed to find out the reasons of low performance in this $\mathrm{CO}$, this was observed that students could not understand/extract auxiliary conditions given due to which they could not solve it properly by not applying the correct auxiliary conditions. This fact is taken into account and the students are clarified about how the extract the auxiliary conditions from the given question and to identify that whether the recursive solution needs to be used or not for the given question.

9. Regarding the students' performance in $\mathrm{CO} 7$ and $\mathrm{CO} 8$, it was observed that the students could not understand the difference between Continuous-Time and Discrete-Time signals and periodic and aperiodic signals due to which they could not apply the proper technique to solve the given question. The is considered and added in the lecture delivery to make the students to identify the difference between Continuous-Time and Discrete-Time signals and periodic and aperiodic signals so that they can understand the given question and solve it with the correct technique.

10. The reasons of student low performance in $\mathrm{CO} 10$ were that the students could not get enough time to comprehend the concepts properly as it was covered near to the end of the semester, therefore, it was planned to cover it in time and give homework and take quizzes from this $\mathrm{CO}$ so that the student can give proper time to this course outcome and could perform better.

\subsection{Course Outcomes Analysis for Spring- Semester}

The students' performance in the course outcome of the course 'Signals and Systems' for Springsemester of 2017-18 is shown in the histogram plot of Figure 7. It is evident that due to the modifications in teaching and learning strategies, the student's performance has significantly improved in COs 2, 3, 4, 5, 6 and 7. However, the student's performance 
has not improved in the $\mathrm{CO} 8$ and $\mathrm{CO} 10$ whereas the student performance has gone down in the $\mathrm{CO} 1$. Therefore, related to $\mathrm{CO} 8$ and $\mathrm{CO} 10$, there needs to be seen further about how to improve student's performance in these COs as previous modifications in the teaching and learning strategies have not worked well which needs further attention. Figure 8 shows the histogram plot of student outcome's EAMU average based on 5-point scale for the Spring-semester of 2017-18. It is evident that the student's performance in SO_11 has significantly improved whereas with regards to SO_1 and SO_9, the student's performance has improved, but SO_1 needs further attention to improve student's performance in this SO.

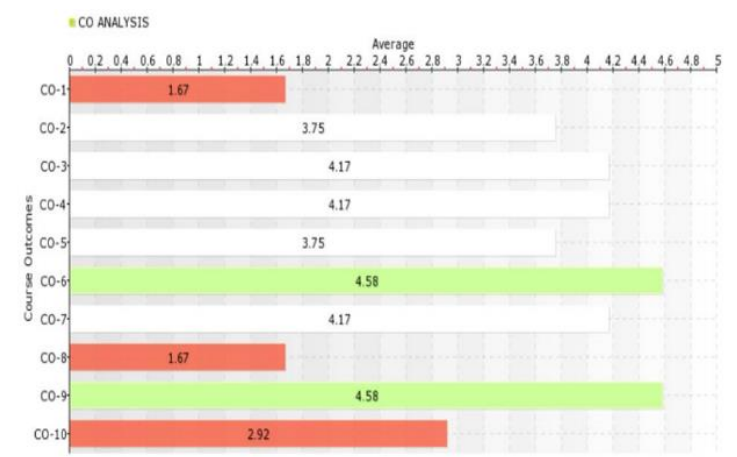

Figure 7. Course outcomes EAMU average based on 5-point scale for the Spring-semester of 2017-18

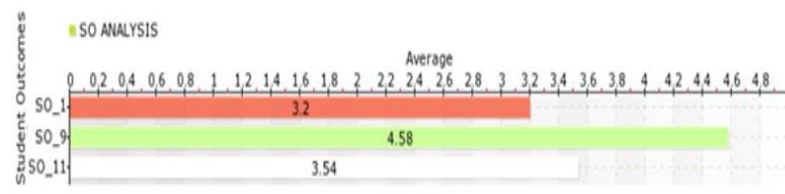

Figure 8. Student outcomes EAMU average based on 5-point scale for the Spring-Semester of 2017-18

\section{Conclusions}

The course outcomes, and specific performance indicators related to the 'Signals and Systems' course taught to the bachelor's students of Electrical Engineering and ABET student outcome coverage by the course outcomes of this course are discussed in this paper. The student's performance as per the course outcomes of the course 'Signals and Systems' for Fall-semester of 2017-18 are shown to highlight the failing $\mathrm{COs}$ in this course. The modifications done in teaching and learning strategies and different methodologies adopted to improve student's performance in the failing COs is discussed and the results achieved by these modified strategies are shown to highlight the significant student's improvement in different COs whereas the student' performance in two COs are not improved which need further attention and change of teaching strategies and methodologies is required to improve student performance related to those COs.

\section{References}

[1] W. Spady, "Outcome-based education: Critical issues and answers," Arlington, VA: American Association of School Administrators, 1994.

[2] W. Spady, "Choosing Outcomes of Significance." Educational Leadership vol. 51, no. 5, 1994, pp. 18-23.

[3] N. Abbadeni, A. Ghoneim, and A. Alghamdi, "Program Educational Objectives Definition and Assessment for Quality and Accreditation," International Journal of Engineering Pedagogy, Vol. 3, no. 3, July 2013, pp. 33-46.

[4] Accreditation Board of Engineering and Technology (ABET): http://www.abet.org

[5] ABET Criteria for Accrediting Engineering Programs, 2018 - 2019: https://www.abet.org/ accreditation/accreditation-criteria/criteria-for-accreditingengineering-programs-2018-2019/. (Access date: 29 January 2019).

[6] ABET Student Outcomes, 2018-2019: https://www.abet.org/accreditation/accreditationcriteria/criteria-for-accrediting-engineering-programs -2018-2019/\#GC3. (Access date: 2 February 2018).

[7] R. M. Felder and R. Brent, "Designing and Teaching Courses to Satisfy the ABET Engineering Criteria." Journal of Engineering Education, Vol. 92, no. 1, 2003, pp. $7-25$.

[8] U. A. U. Amirulddin, M. Osman, F. A. Hamid, "Analysis of Programme Outcomes Achievement for Electrical Engineering Programmes in UNITEN," 2009 International Conference on Engineering Education (ICEED 2009), Kuala Lumpur, Malaysia, December 7-8, 2009, pp. 148-152.

[9] M.S. Jaafar, N. K. Nordin, R Wagiran, A. Aziz, et al, "Assessment Strategy for an Outcome Based Education", International Conference on Engineering Education, July 2008.

[10] R. A. Rashid, R. Abdullah, A. Zaharim, H. Ahmad Ghulman and M. S. Masodi "Engineering Students Performance Evaluation of Generic Skills Measurement: ESPEGS Model", 5th WSEAS / IASME International Conference on Engineering Education (EE'08), July 22-24, 2008

[11] I. Z. Abidin, A. Anuar and N. H. Shuaib, "Assessing the Attainment of Course Outcomes (CO) for an Engineering Course", International Conference on Teaching and Learning (ICTL), Malaysia, Nov. 2009.

[12] EvalTools Suite, Makteam Sortware, http://www.makteam.com/index.php/higher-ed. (Access date: 4 April 2018). 
[13] W. Hussain, M. F. Addas, and F. Mak, "Quality improvement with automated engineering program evaluations using performance indicators based on Bloom's 3 domains," 2016 IEEE Frontiers in Education Conference (FIE), Erie, PA, USA, October 12-15, 2016.

[14] F. Mak and J. Kelly, "Systematic means for identifying and justifying key assignments for effective rules based program evaluation," 40th ASEE/IEEE Frontiers in Education Conference (FIE), Washington, DC, USA, October 27-30, 2010.

[15]http://engineering.iu.edu.sa/index.php/eamu-vectorcalculation/. (Access date: 3 March 2018) 